\title{
Efektivitas penggunaan gambir sebagai bahan penyamak nabati sistem C-RFP untuk pembuatan kulit jaket dari kulit domba
}

\section{Effectiveness of the use of gambier as a vegetable tanning material using the C-RFP system for the manufacture of sheepskin leather for jackets}

\author{
Sri Sutyasmi \\ Balai Besar Kulit, Karet, dan Plastik, Jl. Sokonandi No.9, Yogyakarta 55166, Indonesia \\ Telp: +62 274 512929, 563939; Fax: +62 274563655 \\ E-mail: srisutyasmi@ymail.com
}

Diterima: 20 September 2016 Direvisi: 7 Februari 2017 Disetujui: 7 Februari 2017

\begin{abstract}
Gambier is obtained from the extraction of leaves and young twigs of Uncaria gambir, a shrub that grows in Indonesia. Gambier contains tannin by $20 \%$ to $55 \%$ so that can be used as a vegetable tanning material using the $C$-RFP system ( $C=$ Conditioning, $R=$ Rapid, $F=F a s s$ (drum), $P=P$ Powder). This research aimed to determine the effectiveness of gambier as a vegetable tanning material using the C-RFP system. Pickled leather underwent a tanning process using the C-RFP system with gambier as the tanning material at various percentages, namely by $15 \%, 20 \%$, and $25 \%$, to be processed as leather for jackets. The variations of oil used to keep the leather supple were $12.5 \%, 15 \%$, and $17.5 \%$. The tanned leather was then tested in terms of its organoleptic, physical, chemical, and morphological properties. Results of the organoleptic test and most of the results of the physical test showed that leather for jackets which was tanned using a vegetable tanning material met the requirements set out by SNI 4593: 2011 (sheepskin/goatskin leather for jackets). Results of the SEM test indicated that leather for jackets which was tanned using a vegetable tanning material displayed dense and strong skin tissue, and this proves that gambier is very effective for vegetable tanning using the C-RFP system.
\end{abstract}

Keywords: C-RFP, gambier, vegetable tanning, environmentally friendly.

\begin{abstract}
ABSTRAK
Gambir diperoleh dari ekstraksi daun dan ranting muda Uncaria gambir, merupakan tanaman semak yang tumbuh di Indonesia. Gambir mengandung tanin sebesar 20\%-55\%, sehingga dapat digunakan sebagai bahan penyamak nabati dengan sistem Conditioning - Rapid Fass Powder (C-RFP). Tujuan penelitian ini adalah mengetahui seberapa besar efektivitas gambir sebagai bahan penyamak nabati dengan sistem C-RFP. Kulit pikel disamak dengan sistem C-RFP menggunakan bahan penyamak gambir dengan variasi 15\%, 20\%, dan 25\% untuk menjadi kulit jaket. Variasi minyak yang digunakan agar kulit lemas adalah $12,5 \%, 15 \%$, dan 17,5\%. Kulit tersamak kemudian diuji organoleptis, fisis, kimia, dan morfologi kulit. Hasil uji organoleptis dan sebagian besar hasil uji fisis menunjukkan bahwa kulit jaket samak nabati memenuhi persyaratan SNI 4593:2011 Kulit jaket domba/kambing. Hasil uji SEM menunjukkan kulit jaket samak nabati terlihat jaringan kulit padat dan kuat dan ini menunjukkan bahwa gambir sangat efektif untuk penyamakan nabati dengan sistem C-RFP.
\end{abstract}

Kata kunci: C-RFP, gambir, penyamakan nabati, ramah lingkungan.

\section{PENDAHULUAN}

Kulit di Indonesia merupakan bahan ekspor nonmigas penting sebagai penyumbang devisa yang cukup besar (Setiawan et al., 2015). Mayoritas industri penyamakan kulit menggunakan krom untuk menyamak kulit karena bahan penyamak krom menghasilkan kulit samak yang lebih stabil, tetapi penyamakan dengan bahan penyamak krom berkontribusi terhadap masalah pencemaran lingkungan (Kasim et al., 2012; Kasim et al., 2014). Sebanyak 25\% krom terbuang sebagai limbah (Nasr et al., 2013; Falcão \& Araújo, 2011). Krom valensi 3 yang digunakan untuk penyamakan kulit dapat berubah menjadi krom valensi 6 yang ber- 
sifat karsinogenik di lingkungan, sehingga perlu pengkajian penggunaan bahan penyamak krom untuk diganti yang ramah lingkungan (Koloka \& Moreki, 2011).

Bahan penyamamak nabati adalah bahan penyamak yang ramah lingkungan. Penyamakan nabati adalah proses penyamakan kulit mentah menjadi kulit tersamak dengan menggunakan zat penyamak dari tumbuh-tumbuhan yaitu tanin. Tanin adalah nama generik yang tersebar pada bagian tanaman, seperti: daun, kayu, kulit kayu, ranting, akar, dan buah (Brown \& Shelly, 2011). Tanin mempunyai beberapa sifat seperti amorf, mengencangkan, dan mengawetkan kulit dari serangan mikrobia, serta dapat memberikan warna pada kulit yang disamak (Koloka \& Moreki, 2011). Kayu akasia dan bakau merupakan bahan penyamak nabati yang sering digunakan, tetapi kedua pohon tersebut dilindungi, sehingga dibuat alternatif lain untuk penyamakan nabati menggunakan gambir (Juliyarsi et al., 2013).

Indonesia menjadi pemasok utama gambir dunia $(80 \%)$, sebagian besar berasal dari daerah Provinsi Sumatera Barat terutama dari Kabupaten Lima Puluh Kota. Gambir adalah sejenis getah yang dikeringkan berasal dari ekstrak remasan daun dan ranting tumbuhan yang bernama sama (Uncaria gambir). Gambir banyak digunakan sebagai obat-obatan, penyamak kulit, tinta, dan zat warna. Gambir sebagian besar terdiri dari monomer flavanol seperti catechin, epicatechin, dan alkaloid (Achmad et al., 2012). Gambir sebagai bahan penyamak memiliki berbagai keuntungan yaitu gambir sudah dibudidayakan sehingga selalu tersedia sebagai bahan penyamak kulit tanpa mengganggu kelestarian lingkungan hidup (Kasim et al., 2012). Ketersediaan gambir cukup banyak di Sumatra Barat, kadar tanin gambir diperkirakan antara 20-55\% (Novia, 2009; Setiawan et al., 2015). Dengan dasar itu maka diperlukan zat penyamak yang ramah lingkungan dan menghasilkan kulit samak nabati dengan stabilitas tinggi, memenuhi standar industri, serta dapat membuka peluang pemanfaatan gambir sebagai bahan penyamak kulit.

Conditioning Rapid Fass Powder (C-RFP) adalah suatu sistem samak cepat dimana penyamakan nabati dengan sistem ini adalah penyamakan yang tidak menggunakan air, tapi langsung dengan puder bahan penyamak yang dimasukkan ke dalam drum penyamakan. Air yang digunakan dalam penelitian ini adalah air sisa dari penya- makan sebelumnya. Penyamakan nabati secara konvensional (counter curent) biasanya memerlukan waktu yang lama yaitu sekitar 2 minggu, sedangkan cara C-RFP hanya memerlukan waktu 4 jam.

Penyamakan dengan sistem C-RFP telah dilakukan pada bahan penyamak nabati yang lain yaitu dengan bahan penyamak mimosa. Hasil penelitian menunjukkan bahwa kulit jaket samak nabati yang diproses dengan sistem C-RFP yang menggunakan bahan penyamak mimosa hasil uji organoleptisnya bagus dan memenuhi SNI 4593:2011, demikian juga hasil uji fisis dan morfologi kulit (Sutyasmi et al., 2016). Penelitian ini bertujuan untuk mengetahui sampai dimana efektifitas gambir untuk penyamakan kulit jaket dari domba dengan sistem C-RFP karena gambir diharapkan bisa mengganti mimosa untuk substitusi impor.

\section{BAHAN DAN METODE Bahan Penelitian}

Bahan yang digunakan dalam penelitian ini adalah kulit pikel, bahan penyamak gambir, Soda$\tan$ TSN, Sodapelt CL, syntan, resin, glutaraldehida, cat dasar, minyak, dan asam formiat. Bahan kimia untuk finishing kulit jaket seperti Soft Acrylic RA 1, medium Soft RA 193, Medium urethan/ RU, pigmen, lak, KS 3121.

\section{Peralatan Penelitian}

Peralatan yang digunakan dalam penelitian ini adalah drum penyamakan dengan kapasitas 850 $\mathrm{kg}$. Alat untuk pengujian fisik seperti kuat tarik, kemuluran, kuat sobek menggunakan Zwick/Roell 2020. Alat untuk pengujian tebal menggunakan SG 300. Alat untuk uji derajat penyamakan. Alat untuk pengujian suhu kerut menggunakan alat hasil rekayasa. Alat uji kelemasan menggunakan softness tester ST 300. Alat untuk uji tembus uap air menggunakan water permeability tester STM 473. Alat uji morfologi menggunakan scanning electron microscope (SEM) SEC $3200 \mathrm{M}$.

\section{Metode Penelitian}

Kulit pikel dari kulit domba disamak nabati menggunakan gambir dengan variasi jumlah gambir sebanyak $15 \%, 20 \%$, dan $25 \%$. Hal ini dilakukan untuk mengetahui sampai kadar berapa kulit bisa tersamak matang dengan gambir. Sebelum dilakukan proses penyamakan kulit dilakukan pretanning dengan Sodatan TSN. Penyamakan 
nabati menyebabkan kulit menjadi kaku, padat, dan berisi. Agar kulit menjadi lemas seperti pada penyamakan krom perlu peminyakan yang sesuai sehingga diperlukan variasi penggunaan minyak untuk proses peminyakan. Jenis minyak yang digunakan dalam penelitian ini adalah minyak sintetis yang biasa digunakan untuk fatliquoring pada proses penyamakan. Variasi minyak yang digunakan agar kulit menjadi lemas adalah $12,5 \%$, $15 \%$, dan $17,5 \%$. Tahapan penyamakan kulit jaket pada penelitian ini adalah sebagai berikut: kulit pikel dilakukan pretanning dengan menggunakan air pikel 100\%, garam 7\%, dan Sodatan TSN 4\%, diputar 60 menit, lalu dibuang airnya. Selanjutnya kulit diputar 180 menit dan dicek penyamakannya, gambir bisa tembus ke bagian dalam kulit atau tidak, yaitu dengan mengiris penampang kulit. Pemutaran drum selanjutnya ditambah 60 menit, kemudian dicek suhu kerutnya. Pengikatan zat penyamak menggunakan air $100 \%$, Sodapelt $\mathrm{CL}$ $0,5 \%$, diputar selama 30 menit, lalu dibuang airnya. Selanjutnya kulit dicuci dengan air $75 \%$ dan Sodapelt CL 0,5\%, diputar 20 menit, air dibuang dan dicuci. Kulit kemudian diretanning dengan air $45^{\circ} \mathrm{C}$ sebanyak $100 \%$, syntan $3 \%$, diputar 60 menit, resin 3\%, diputar 60 menit, glutaraldehida $4 \%$, diputar 60 menit, cat dasar $2 \%$ diputar 60 menit, dan peminyakan menggunakan konsentrasi minyak seperti di atas, diputar selama 90 menit. Kulit selanjutnya dilakukan finishing. Perlakuan penyamakan kulit ini sama dengan penyamakan nabati menggunakan bahan penyamak mimosa.
Kulit jaket yang dihasilkan diuji sesuai dengan SNI 4593:2011 Kulit jaket domba/kambing, dan juga uji SEM untuk mengetahui morfologi kulit.

\section{HASIL DAN PEMBAHASAN Uji Organoleptis}

Tabel 1 menunjukkan bahwa semua parameter hasil uji organoleptis baik dan memenuhi SNI 4593:2011, yaitu keadaan kulit semuanya lemas, warna semuanya rata, kelepasan nerf tidak lepas, dan elastik. Apabila dibandingkan dengan hasil uji kulit yang disamak dengan sistem C-RFP menggunakan mimosa (Sutyasmi et al., 2016) maka penyamakan dengan bahan penyamak gambir tidak lebih jelek dari mimosa. Hasil uji organoleptis kulit samak nabati yang disamak dengan mimosa mempunyai hasil uji organoleptis yang sama dengan gambir. Penyamakan dengan gambir ini mempunyai suhu kerut $76^{\circ} \mathrm{C}$ sedangkan penyamakan dengan mimosa mempunyai suhu kerut sedikit lebih tinggi yaitu $82^{\circ} \mathrm{C}$. Hal ini mungkin dikarenakan penyamakan dengan bahan penyamak gambir mempunyai kadar tanin yang lebih rendah dari pada bahan penyamak mimosa. Bahan penyamak mimosa mempunyai kadar tanin sekitar $70 \%$, sedangkan gambir mempunyai kadar tanin antara 20\%-55\%. Mimosa adalah sari kulit kayu akasia (Acasia deoureus) yang sudah diproses dengan bahan-bahan kimia, sehingga mempunyai kadar tanin yang tinggi, sedangkan gambir yang digunakan dalam penelitian ini adalah murni berasal dari getah daun dan ranting

Tabel 1. Hasil uji organoleptis kulit samak nabati (gambir) dengan sistem C-RFP.

\begin{tabular}{lcccccccccc}
\hline & Bahan penyamak & \multicolumn{10}{c}{ Gambir } \\
\cline { 2 - 11 } Macam uji & G1.1 & G1.2 & G1.3 & G2.1 & G2.2 & G2.3 & G3.1 & G3.2 & G3.3 \\
\hline Keadaan kulit & Lemas & Lemas & Lemas & Lemas & Lemas & Lemas & Lemas & Lemas & Lemas \\
Warna & Rata & Rata & Rata & Rata & Rata & Rata & Rata & Rata & Rata \\
Kelepasan nerf & Tidak & Tidak & Tidak & Tidak & Tidak & Tidak & Tidak & Tidak & Tidak \\
Elastisitas & lepas & lepas & lepas & lepas & lepas & lepas & lepas & lepas & lepas \\
& Elastis & Elastis & Elastis & Elastis & Elastis & Elastis & Elastis & Elastis & Elastis \\
\hline
\end{tabular}

Keterangan: G.1.1: Bahan penyamak gambir 15\% dan minyak 12,5\%; G.1.2: Bahan penyamak gambir $15 \%$ dan minyak $15 \%$; G.1.3: Bahan penyamak gambir $15 \%$ dan minyak 17,5\%; G.2.1: Bahan penyamak gambir 20\% dan minyak 12,5\%; G.2.2: Bahan penyamak gambir 20\% dan minyak 15\%; G.2.3: Bahan penyamak gambir 20\% dan minyak 17,5\%; G.3.1: Bahan penyamak gambir 25\% dan minyak 12,5\%; G.3.2: Bahan penyamak gambir 25\% dan minyak 15\%; dan G.3.3: Bahan penyamak gambir 25\% dan minyak $17,5 \%$. 
Tabel 2. Hasil uji dari kulit samak nabati (gambir) sistem C-RFP.

\begin{tabular}{|c|c|c|c|c|c|c|c|c|c|}
\hline \multirow{2}{*}{ Macam uji } & \multicolumn{9}{|c|}{ Gambir } \\
\hline & G1.1 & G1.2 & G1.3 & G2.1 & $\mathrm{G} 2.2$ & G2.3 & G3.1 & G3.2 & G3.3 \\
\hline Tebal, mm & 0,68 & 0,60 & 0,56 & 0,68 & 0,56 & 0,52 & 0.72 & 0,64 & 0,58 \\
\hline $\begin{array}{l}\text { Kekuatan sobek, } \\
\mathrm{N} / \mathrm{cm}\end{array}$ & 190 & 162 & 154,8 & 159,4 & 120,8 & 123,2 & 143,5 & 132,3 & 119,3 \\
\hline Kekuatan tarik, $\mathrm{N} / \mathrm{cm}^{2}$ & 173,4 & 187,3 & 103,8 & 139,3 & 137 & 77,39 & 230,5 & 257,5 & 130,7 \\
\hline Kemuluran, \% & 55 & 41,99 & 37,44 & 51,66 & 31,03 & 27,49 & 51,53 & 45,07 & 33,17 \\
\hline \multicolumn{10}{|l|}{$\begin{array}{l}\text { Ketahanan gosok cat } \\
\text { tutup, }\end{array}$} \\
\hline - Kering & $4 / 5$ & $4 / 5$ & $4 / 5$ & $4 / 5$ & $4 / 5$ & $4 / 5$ & $4 / 5$ & $4 / 5$ & $4 / 5$ \\
\hline - Basah & $4 / 5$ & $4 / 5$ & $4 / 5$ & $4 / 5$ & $4 / 5$ & $4 / 5$ & $4 / 5$ & $4 / 5$ & $4 / 5$ \\
\hline $\begin{array}{l}\text { Tembus uap air, } \\
\mathrm{mg} / \mathrm{cm}^{2} / \mathrm{jam}\end{array}$ & 7,01 & 18,58 & 8,44 & 9,61 & 11,3 & 12,63 & 11,41 & 10,51 & 10,04 \\
\hline
\end{tabular}

Keterangan: G.1.1: Bahan penyamak gambir 15\% dan minyak 12,5\%; G.1.2: Bahan penyamak gambir $15 \%$ dan minyak $15 \%$; G.1.3: Bahan penyamak gambir $15 \%$ dan minyak 17,5\%; G.2.1: Bahan penyamak gambir $20 \%$ dan minyak $12,5 \%$; G.2.2: Bahan penyamak gambir $20 \%$ dan minyak $15 \%$; G.2.3: Bahan penyamak gambir 20\% dan minyak 17,5\%; G.3.1: Bahan penyamak gambir $25 \%$ dan minyak $12,5 \%$; G.3.2: Bahan penyamak gambir $25 \%$ dan minyak $15 \%$; dan G.3.3: Bahan penyamak gambir $25 \%$ dan minyak $17,5 \%$.

gambir yang dipadatkan. Hasil uji kadar tanin gambir yang digunakan dalam penelitian ini adalah $78,83 \%$, sedangkan mimosa mempunyai kadar tanin lebih dari $80 \%$.

\section{Uji Fisis}

Dari data pengujian fisis (Tabel 2) dapat dilihat bahwa untuk pengujian tebal rata-rata antara 5,6-7,2. Hal ini cukup untuk ketebalan kulit jaket. Ketebalan kulit tergantung dari proses shaving kulit tersebut. Kekuatan sobek adalah besarnya gaya maksimal yang digunakan untuk menyobek kulit yang disamak dengan bahan penyamak gambir. Dari data pengujian kekuatan sobek terlihat bahwa untuk penyamakan gambir dengan variasi minyak $12,5 \%$ dan bahan penyamak gambir $15 \%$, $20 \%$, dan $25 \%$ mempunyai kekuatan sobek yang lebih besar dibandingkan dengan kekuatan sobek pada kulit yang menggunakan variasi minyak $15 \%$ dan $20 \%$. Hal ini ditunjukkan oleh G1.1, G2.1, dan G3.1, yang mempunyai nilai kekuatan sobek masing-masing $190 ; 159,4 ; 143$, dan pada variasi minyak $15 \%$ dan $17,5 \%$ mempunyai nilai $162 ; 120,8 ; 132,3$ dan 154,$8 ; 123,2 ; 119,3$. Kecenderungan ini kemungkinan disebabkan oleh ketebalan kulit yang kurang memenuhi SNI 4593:2011 sehingga kulit mudah sobek. Tebal tipis kulit samak mempengaruhi kekuatan sobek karena serat kolagen pada kulit yang tipis cenderung longgar sehingga mudah disobek. Selain tebal tipisnya kulit, kekuatan sobek juga dipengaruhi oleh banyaknya minyak yang diserap oleh kulit (Setiawan et al., 2015).

Hasil uji kekuatan tarik tertinggi terdapat pada penyamakan dengan gambir yang menggunakan variasi gambir $25 \%$ dan minyak $15 \%$. Ini berarti ada pengaruh penggunaan minyak yaitu pada penggunaan minyak $12,5 \%$ kekuatan tariknya lebih rendah (penggunaan minyak kurang), sedangkan penggunaan minyak lebih dari $15 \%$ kekuatan tariknya menurun. Ini berarti penggunaan minyak yang tepat adalah $15 \%$ dan gambir $25 \%$, yaitu sebesar $257,5 \mathrm{~N} / \mathrm{cm}^{2}$. Sedangkan hasil uji kekuatan tarik terendah adalah variasi gambir $20 \%$ dan minyak $17,5 \%$ yaitu sebesar $77,39 \mathrm{~N} / \mathrm{cm}^{2}$. Hasil uji tebal, kekuatan sobek dan kekuatan tarik ada- 
Tabel 3. Hasil uji kimia kulit jaket samak nabati

\begin{tabular}{lccccccccc}
\hline & \multicolumn{7}{c}{ Bahan penyamak } & \multicolumn{7}{c}{ Gambir } \\
\cline { 2 - 9 } Macam uji & G1.1 & G1.2 & G1.3 & G2.1 & G2.2 & G2.3 & G3.1 & G3.2 & G3.3 \\
\hline Kadar air, \% (b/b) & 16 & 16 & 16 & 13 & 13 & 13 & 14 & 14 & 14 \\
$\begin{array}{l}\text { Kadar lemak, \% (b/b) } \\
\text { Kadar nitrogen, \% }\end{array}$ & 15,95 & 18,32 & 20,31 & 15,82 & 16,20 & 16,86 & 15,11 & 15,50 & 16,67 \\
$\begin{array}{l}\text { K/b) } \\
\text { (b/b) }\end{array}$ & 6,50 & 6,58 & 6,80 & 6,52 & 6,41 & 6,42 & 6,47 & 6,45 & 6,25 \\
$\begin{array}{l}\text { Kadar zat larut dalam } \\
\text { air, \% (b/b) }\end{array}$ & 3,46 & 3,32 & 3,11 & 3,45 & 3,31 & 3,12 & 3,31 & 3,30 & 3,12 \\
$\begin{array}{l}\text { Kadar abu tak larut, } \\
\text { \% (b/b) }\end{array}$ & 1,60 & 1,42 & 1,44 & 1,61 & 1,40 & 1,42 & 1,62 & 1,43 & 1,41 \\
$\begin{array}{l}\text { Kadar zat Kulit } \\
\text { mentah, \% (b/b) }\end{array}$ & 36,56 & 34,98 & 33,24 & 36,58 & 35,98 & 35,27 & 36,54 & 36,16 & 35,26 \\
$\begin{array}{l}\text { Kadar tanin terikat, } \\
\text { \% (b/b) }\end{array}$ & 19,93 & 19,38 & 19,10 & 23,02 & 23,70 & 23,91 & 22,95 & 23,16 & 23,29 \\
$\begin{array}{l}\text { Derajat penyamakan, } \\
\text { \% }\end{array}$ & 54,51 & 55,40 & 57.46 & 62,93 & 65,87 & 67,79 & 62,80 & 64,05 & 66,05 \\
\hline
\end{tabular}

Keterangan: G.1.1: Bahan penyamak gambir 15\% dan minyak 12,5\%; G.1.2: Bahan penyamak gambir $15 \%$ dan minyak $15 \%$; G.1.3: Bahan penyamak gambir $15 \%$ dan minyak 17,5\%; G.2.1: Bahan penyamak gambir $20 \%$ dan minyak 12,5\%; G.2.2: Bahan penyamak gambir 20\% dan minyak 15\%; G.2.3: Bahan penyamak gambir $20 \%$ dan minyak $17,5 \%$; G.3.1: Bahan penyamak gambir $25 \%$ dan minyak $12,5 \%$; G.3.2: Bahan penyamak gambir $25 \%$ dan minyak $15 \%$; dan G.3.3: Bahan penyamak gambir $25 \%$ dan minyak $17,5 \%$.

lah saling terkait, yaitu apabila tebal kulit cukup (memenuhi SNI 4593:2011) maka kekuatan sobek dan kekuatan tarik juga akan memenuhi SNI yang dipersyaratkan (Tabel 2).

Kemuluran adalah bertambah panjangnya kulit tersamak saat ditarik sampai kulit tersamak tersebut dapat mudah terputus. Kemuluran dipengaruhi oleh komposisi protein serat di dalam kulit atau kondisi awal kulit, sehingga bahan penyamak tidak memengaruhi kemuluran kulit serta proses bating (Setiawan et al., 2015).

Menurut Kasim et al. (2013) prinsip proses penyamakan nabati adalah menggunakan zat penyamak dengan molekul kecil, daya ikat kecil, sehingga penetrasinya cepat, kulit yang dihasilkan tidak mengalami kontraksi, kemudian molekul dan daya ikat pada kulit diperbesar dengan cara mengubah kepekatan dan $\mathrm{pH}$ sehingga kulit menjadi tersamak dengan rata.

Ketahanan gosok cat baik basah maupun kering semuanya tidak luntur dengan nilai $4 / 5$. Hasil uji tembus uap air semua memenuhi SNI
4593:2011 yang pada persyaratan minimal 2,50 $\mathrm{mg} / \mathrm{cm}^{2} / \mathrm{jam}$, sedangkan hasil uji kulit hasil penelitian antara $7-12 \mathrm{mg} / \mathrm{cm}^{2} / \mathrm{jam}$.

\section{Uji Kimia}

Hasil uji kimia dari kulit yang disamak dengan gambir sistem C-RFP dapat dilihat pada Tabel 3. Derajat penyamakan (tingkat kemasakan kulit tersamak) merupakan jumlah zat penyamak (tanin) yang dapat terikat pada kulit dibandingkan dengan kulit yang tidak tersamak (zat kulit mentah) dari kulit hasil penyamakan dengan gambir. Besarnya derajat penyamakan akan memengaruhi sifat fisik kulit seperti tekstur (lunak, lemas), sifat mengembang, dan ketahanan kulit terhadap perlakuan tambahan. Semakin tinggi derajat penyamakan semakin baik kualitas kulit. Dilihat dari data hasil uji tanin terikat maka dapat diketahui bahwa hasil uji tanin terikat pada kulit nabati yang disamak dengan sistem C-RFP dengan bahan penyamak gambir mempunyai nilai antara 19\%-23\%. Data dari hasil uji derajat penyamakan 
menunjukkan bahwa semakin besar zat penyamak yang digunakan untuk menyamak kulit maka derajat penyamakannya semakin besar.

Derajat penyamakan dengan penggunaan gambir $15 \%$ dan penggunaan minyak $12,5 \%$ terlihat bahwa gambir mempunyai derajat penyamakan yang memenuhi syarat untuk penyamakan nabati karena penyamakan nabati paling rendah harus mempunyai derajat penyamakan minimal $50 \%$. Hal ini juga berlaku pada penggunaan gambir $20 \%$ dan $25 \%$. Semakin tinggi zat penyamak yang digunakan untuk penyamakan kulit ini maka derajat penyamakannya juga semakin besar, namun pada konsentrasi gambir $25 \%$, hasil uji derajat penyamakannya sedikit menurun. Hal ini kemungkinan disebabkan karena penggunaan bahan penyamak nabati dengan konsentrasi yang tinggi menyebabkan penetrasi ke dalam kulit rendah. Hal ini sesuai dengan pendapat Kasim et al. (2013), bahwa zat penyamak nabati pada konsentrasi yang tinggi memiliki molekul yang lebih besar dibandingkan dengan konsentrasi rendah (daya samak tinggi namun penetrasi ke dalam kulit rendah).

Menurut Haron et al. (2012), tanin dalam proses penyamakan secara kimia bereaksi dengan kulit membentuk crosslinks dengan kolagen kulit, grup tanin aktif berikatan dengan grup protein yang ada di dalam kulit.

Penurunan nilai kadar zat penyamak terikat disebabkan oleh zat penyamak gambir merupakan bahan penyamak yang mudah berpenetrasi ke dalam kulit, tetapi tidak bersenyawa dengan baik. Ukuran partikel gambir sebagai bahan penyamak adalah $126 \mathrm{~nm}$, sedangkan mimosa mempunyai ukuran partikel 100,5 nm. Dengan demikian karena ukuran partikel gambir hanya sedikit lebih besar dari pada ukuran partikel mimosa dan mimosa dalam pembuatannya juga ditambah dengan bahan kimia, maka gambir juga efektif untuk menyamak kulit menggantikan mimosa yang merupakan produk impor. Jumlah tanin yang terikat pada kulit dipengaruhi oleh jumlah tanin yang dapat terdifusi ke dalam jaringan kulit (Kasim et al., 2013).

SNI 4593:2011 adalah SNI kulit jaket domba/ kambing samak krom yang nilainya seperti Tabel 4. Sedangkan kulit jaket hasil penelitian adalah kulit samak nabati (tidak mengandung krom), sehingga ada parameter yang tidak bisa dibandingkan.
Tabel 4. SNI 4593:2011 Persyaratan mutu kulit jaket domba kambing.

\begin{tabular}{|c|c|c|}
\hline No & Jenis Uji & Syarat Mutu \\
\hline 1 & Organoleptis & \\
\hline 1.1 & Warna & rata \\
\hline 1.2 & Kelepasan nerf & Tidak lepas \\
\hline 1.3 & Elastisitas & elastis \\
\hline 2 & Fisis & \\
\hline 2.1 & Tebal, mm & $0.4-0,8$ \\
\hline 2.2 & Kekuatan sobek, N/mm & $\operatorname{Min} 12,5$ \\
\hline 2.3 & Penyamakan & Masak \\
\hline & Penyusutan, \% & Maks. 10 \\
\hline 2.4 & Kekuatan tarik, N/mm² & Min. 14 \\
\hline 2.5 & Kemuluran, \% & Maks. 60 \\
\hline 2.6 & $\begin{array}{l}\text { Ketahanan gosok cat } \\
\text { tutup, grey scale }\end{array}$ & \\
\hline & a. Kering & Min. 4/5 \\
\hline & b. Basah & Min. 4 \\
\hline 2.7 & $\begin{array}{l}\text { Tembus uap air, } \\
\mathrm{mg} / \mathrm{cm}^{2} / \mathrm{j}\end{array}$ & Min. 2,50 \\
\hline 2.8 & Kelemasan, mm & $5,0-7,5$ \\
\hline 3 & Kimia & \\
\hline 3.1 & Kadar air, \% (b/b) & Maks.18 \\
\hline 3.2 & $\begin{array}{l}\text { Kadar krom oksida, } \\
\%(b / b)\end{array}$ & $2,5-3,0$ \\
\hline 3.3 & $\begin{array}{l}\text { Kadar abu jumlah } \\
\%(b / b)\end{array}$ & $\begin{array}{c}\text { Maks. 2,0 di } \\
\text { atas kadar krom } \\
\text { oksida }\end{array}$ \\
\hline 3.4 & $\begin{array}{l}\text { Kadar lemak/minyak, } \\
\%(b / b)\end{array}$ & $8,0-15$ \\
\hline 3.5 & $\mathrm{pH}$ & $3,5-7,0$ \\
\hline
\end{tabular}

\section{Uji SEM}

Dari Gambar 1 dapat diketahui bahwa zat penyamak gambir mempunyai butiran yang tidak teratur sehingga untuk penyamakan nabati dengan sistem C-RFP menggunakan gambir perlu pencampuran zat penyamak gambir dengan kulit yang lebih baik agar zat penyamak bisa merata masuk kedalam kulit. Sedangkan SEM pada kulit hasil penyamakan dengan gambir pada perbesaran 2500 kali untuk kulit yang disamak dengan gambir $15 \%$ atau kode G1 terlihat sangat kompak jaringan dari kulit tersebut dan penyamakannya rata, walaupun masih ada sisa zat penyamak gambir yang belum masuk ke dalam kulit. Hal ini membuktikan bahwa gambir efektif bisa digunakan untuk bahan penyamak nabati sistem C-RFP dan waktu yang digunakan untuk menyamak cukup, karena apabila dilihat dari suhu kerut penyamakan tersebut adalah $76^{\circ} \mathrm{C}$ dan ini berarti penyamakannya masak. Demikian pula apabila dikait- 


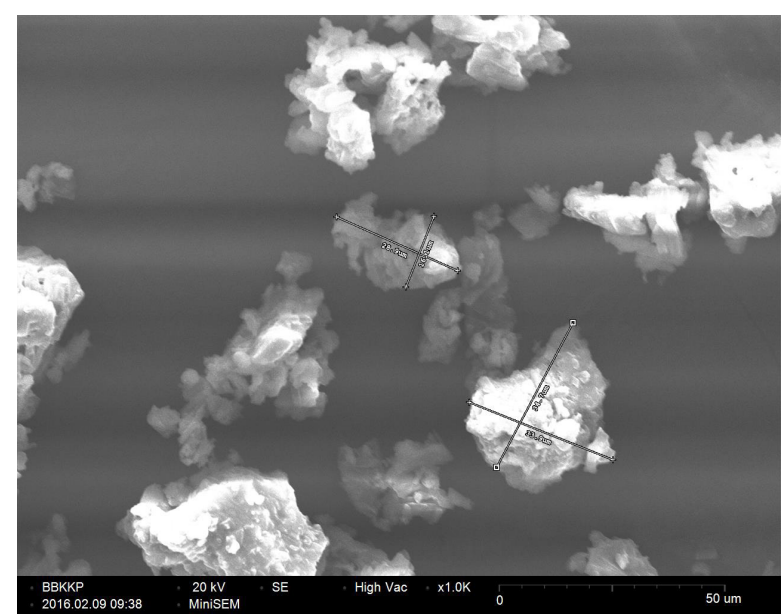

(a)

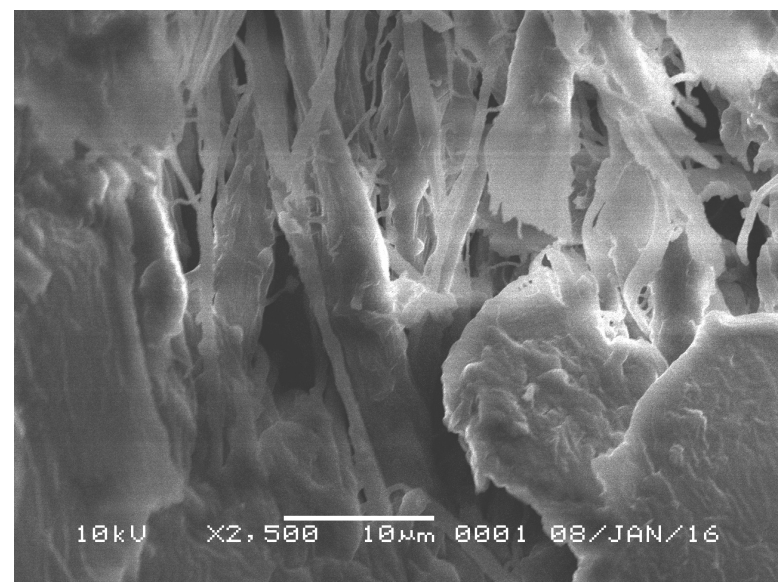

(c)

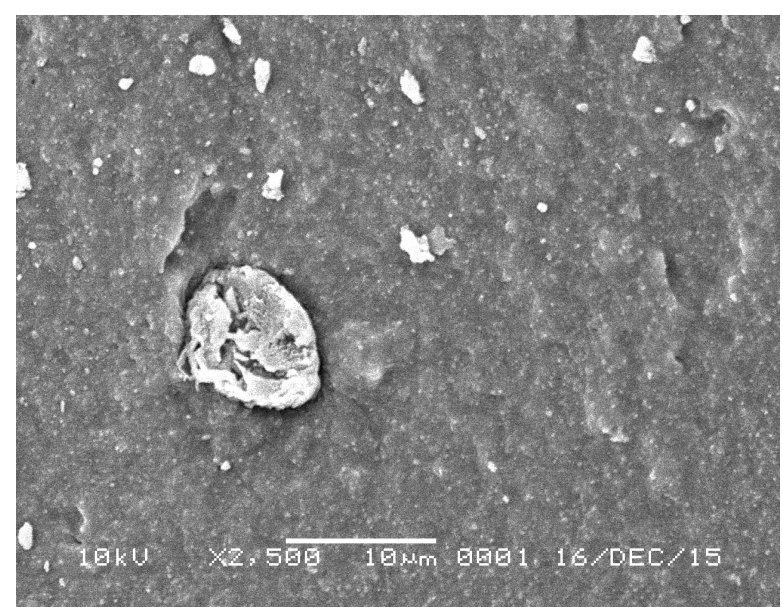

(b)

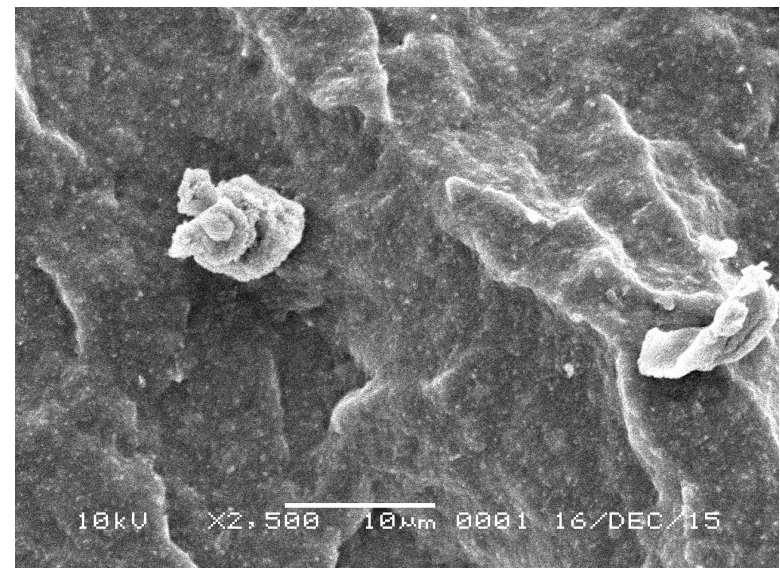

(d)

Gambar 1. Hasil uji SEM: (a) Bahan penyamak gambir, (b) G1.2. (kulit samak dengan gambir 15\% dan minyak 15\%), (c) G2.2. (kulit samak dengan gambir 20\% dan minyak 15\%), (d) G3.2 (kulit samak dengan gambir $25 \%$ dan minyak $15 \%$ ).

kan dengan kekuatan tarik pada kode G1 atau penggunaan gambir 15\%, kekuatan tariknya besar dan kemuluran juga memenuhi SNI 4593:2011 (SNI Kulit jaket domba/kambing).

Pada gambar SEM dengan bahan penyamak gambir $20 \%$ atau kode $\mathrm{G} 2$ kulit juga terlihat padat dan jaringan kompak sehingga apabila dikaitkan dengan kekuatan tarik dan kemuluran juga memenuhi SNI 4593:2011. Pada gambar SEM dengan bahan penyamak gambir sebesar $25 \%$ atau kode G3, kulit terlihat semakin padat namun masih ada sisa gambir yang berupa titik-titik pada gambar SEM yang membuktikan bahwa zat penyamak gambir masih ada yang tertinggal dan tidak masuk ke dalam kulit. Apabila dikaitkan dengan hasil uji kekuatan tarik dan kemuluran juga masih memenuhi SNI 4593:2011. Hal ini membuktikan bahwa menapa pada uji kimia yaitu derajat penyamakan pada kulit dengan bahan penyamak gam- bir 25\% sedikit menurun, karena dalam gambar SEM terlihat masih ada sisa zat penyamak yang belum seluruhnya masuk ke dalam kulit. Hal ini disebabkan karena penggunaan bahan penyamak yang tinggi menyebabkan penetrasi ke dalam kulit rendah karena konsentrasi bahan penyamak yang tinggi memiliki molekul yang lebih besar dibanding dengan konsentrasi rendah. Dengan kata lain daya samak tinggi namun penetrasi rendah sehingga dalam gambar SEM terlihat masih ada butiran-butiran gambir yang tidak masuk ke dalam kulit (Kasim et al., 2013). Hal ini juga terlihat pada hasil uji kimia pada konsentrasi 25\% maka derajat penyamakannya sedikit naik.

\section{KESIMPULAN}

Uncaria gambir merupakan bahan penyamak nabati yang cukup efektif untuk digunakan sebagai bahan penyamak kulit jaket menggantikan mi- 
mosa yang masih merupakan bahan impor. Hasil uji kulit yang disamak dengan bahan penyamak gambir secara organoleptis sama dengan kulit jaket dengan bahan penyamak mimosa. Hasil uji fisis dan kimia kulit yang disamak dengan gambir hampir semuanya memenuhi SNI 4593:2011 (kulit jaket domba/kambing). Sedangkan hasil uji SEM menunjukkan bahwa zat penyamak kulit masuk ke dalam kulit dengan baik dan merata, ini membuktikan bahwa gambir juga efektif untuk menyamak kulit dengan bahan penyamak nabati seperti mimosa, yang artinya dapat menggantikan substitusi impor. Variasi minyak dan Uncaria gambir yang tepat untuk digunakan menyamak kulit jaket domba/kambing adalah $15 \%$.

\section{UCAPAN TERIMA KASIH}

Penulis mengucapkan terimakasih kepada Kepala Balai Besar Kulit, Karet dan Plastik yang telah memberi kepercayaan dan dana untuk melakukan penelitian, serta kepada semua anggota tim pokja 1866.001.011D dan semua personil yang telah membantu dalam pelaksanaan kegiatan penelitian ini.

\section{DAFTAR PUSTAKA}

Achmad, A., Kassim, J., Suan, T. K., Amat, R. C., \& Seey, T. L. (2012). Equilibrium, kinetic and thermodynamic studies on the adsorption of direct dye onto a novel green adsorbent developed from Uncaria Gambir extract. Journal of Physical Science, 23(1), 1-13.

Brown, E., \& Shelly, D. (2011). Molecular modeling approach to vegetable tanning: preliminary results for gallotannin interactions with the collagen microfibril. Journal of the American Leather Chemists Association, 106(5), 145-152.

Falcão, L., \& Araújo, M. E. M. (2011). Tannins characterisation in new and historic vegetable tanned leathers fibres by spot tests. Journal of Cultural Heritage, 12(2), 149-156. https://doi.org/10.1016/j.culher.2010.10.005

Haron, M. A., Khirstova, P., Gasmelseed, G. A., \& Covington, A. (2012). Potential of vegetable tanning materials and basic aluminum sulphate in Sudanese Leather Industry (Part II). Suranaree Journal of Science and Technology, 19(1), 31-41.
Juliyarsi, I., Novia, D., \& Helson, J. (2013). Kajian penambahan gambir sebagai bahan penyamak nabati terhadap mutu kimiawi kulit kambing. Jurnal Peternakan Indonesia, 15(1), 35-45.

Kasim, A., Novia, D., \& Mutiar, S. (2014). Diminishing chromium use on combined chromium-gambier tanning process upon the characteristics of tanned leather. Media Peternakan, 37(1), 24-29. https://doi.org/10.5398/medpet.2014.37.1.24

Kasim, A., Novia, D., Mutiar, S., \& Pinem, J. (2013). Karakterisasi kulit kambing pada persiapan penyamakan dengan gambir dan sifat kulit tersamak yang dihasilkan. Majalah Kulit Karet dan Plastik, 29(1), 1-12. https://doi.org/10.20543/mkkp.v29i1.213

Kasim, A., Nurdin, H., \& Mutiar, S. (2012). Aplikasi gambir sebagai bahan penyamak kulit melalui penerapan penyamakan kombinasi. Jurnal Litbang Industri, 2(2), 55-62.

Koloka, O., \& Moreki, J. C. (2011). Tanning hides and skins using vegetable tanning agents in Hukuntsi sub-district, Botswana. Journal of Agricultural Technology, 7(4), 915-922.

Nasr, A. I., Abdelsalam, M. M., \& Azzam, A. H. (2013). Effect of tanning method and region on physical and chemical properties of Barki sheep leather. Egyptian Journal of Sheep and Goat Sciences, 8(1), 123-130. https://doi.org/10.12816/0005033

Novia, D. (2009). Pengaruh perlakuan awal daun/ ranting tanaman gambir (Uncaria gambir roxb) terhadap kadar tannin ekstrak yang dihasilkan dan kemampuan penyamakannya pada kulit kambing. Jurnal Peternakan, 6(1), 22-28.

Setiawan, A., Hariyadi, P., \& Sumardianto, S. (2015). Pengaruh penggunaan gambir (Uncaria gambier) sebagai bahan penyamak pada proses penyamakan kulit terhadap kualitas fisik kulit ikan nila (Oreochromis niloticus). Jurnal Pengolahan dan Bioteknologi Hasil Perikanan, 4(2), 124-132.

Sutyasmi, S., Widowati, T. P., \& Setyadewi, N. M. (2016). Pengaruh mimosa pada penyamakan kulit jaket domba samak nabati menggunakan sistem C-RFP, ditinjau dari sifat organoleptis, fisis, dan morfologi kulit. Majalah Kulit, Karet, dan Plastik, 32(1), 31-38.

https://doi.org/10.20543/mkkp.v32i1.932 